\title{
EXTRACTION AND UTILIZATION OF LANDFILL GAS
}

\author{
Bo Lennart Persson \\ DeponiGasTeknik, Malmö \\ Sweden
}

\begin{abstract}
DeponiGasTeknik DGT AB is a consulting firm working in the Environment and Energy sector. A special field is to design and develope plants for extraction and utilization of landfill gas. Amoung the plants that DeponiGasTeknik has designed through the years are a new compressorstation in Helsingborg. Other interesting projects are the fixed link across Öresund where DeponiGasTeknik has design a system on the old landfill to prevent gas to penetrate the railway and highway area. An other project is the digestercells in Växjö which are a development of the common biocells. Finally are an example presented on the closed digesters that DeponiGasTeknik has designed in Helsingborg for around 30000 $40000 \mathrm{~m}^{3}$ waste per year.
\end{abstract}

\section{DeponiGasTeknik}

DeponiGasTeknik DGT AB is a consulting firm which is working in the Environment and Energy sector. In the Environment and Energy sector DeponiGasTeknik mostly works with municipal and goverment agencies. A special field, where DeponiGasTeknik is the leading firm in Sweden, is to design and develope plants for extraction and utilization of gas from landfill.

Other special competence areas are design of landfills and biocells, treatment of leachate from landfills and anaerobic digestion of solid waste in closed digesters.

DeponiGasTeknik is working in the Nordic states and some other countries in Europe.

In the following presentation will four different projects, that DeponiGasTeknik has been involved in, be described. 


\section{COMPRESSORSTATION-NSR, HELSINGBORG}

In 1985 a plant for extraction and utilization of the landfill gas was built in Helsingborg as the second plant in Sweden. After nine years it was time to construct and build a new compressorstation.

The station has a capacity for $13 \mathrm{MW}$ and the gas is delivered to three gardens, a powerstation and to the facilities on the landfill. Around $2000 \mathrm{~m}^{3} / \mathrm{h}$ or $10 \mathrm{MW}$ are produced today. In the station there are 4 compressors that give the gas a pressure of around 1,5 BarA. The gas are cooled to a temperature of around $40^{\circ} \mathrm{C}$.

The distributionsystem consist of PE-pipes with a total length of around $4500 \mathrm{~m}$ and the landfill has an area of around 40 ha. In the landfill there are around 60 drilled gaswells and $4000 \mathrm{~m}$ perforated horizontal PE-pipes.

\section{THE FIXED LINK ACROSS ÖRESUND}

In the year 2000 the link between Copenhagen and Malmö will be ready. It will be a $16 \mathrm{~km}$ long bridge/channel that connects the to cities.

The starting point on the swedish side is on a place called Lemacken. Lernacken is the old landfill for Malmö that was used in the 50's-80's. Since the 70's only some industrial wastes and garden waste were landfilled in Lemacken.

For the preparation of the place for the railway and the highway a big cutting in the old landfill has to be done. Investigations in the landfill showed that there still was a generation of landfill gas in the landfill. In consequence with this a system will be built to insure that gas the from the landfill not will occur in the railway and highway area.

The system of extraction of the gas is divided in to parts. The first part consist of a permeable layer in the cutting that is inforced by perforated PE-pipes. Over this layer a close layer of clay will be layed and hereby a underpressure can be established in the permeable layer to collect the landfill gas. To enforce the gas extraction system, a second part, consisting of drilled gaswells in the border between the slope and the highway, are installated. By this part no gas can travel into and under the highway and the railway area. All gasextraction services are to be connected with a fanstation and a flare on the top of the landfill.

\section{DIGESTIONS-CELLS}

In Sweden the treatment of household waste in biocells has been a new method that have been developed in the 90 's. The method means that the waste is dumped in cells which are surrounded with walls of earthmaterials. In the cells water can be added and the degradation of the organic material goes relatively fast (7-10 years) and the collection of landfill gas can be done effectively. 
Under 1995-1996 DeponiGasTeknik has developed a new kind of biocells called digestions-cells.

In Växjö a pilot plant has been built to test the system. In june 1997 the first waste was filled in the digesters-cells.

The plant is constructed of concrete with three walls and floor of concrete. When the cell is filled up with waste it will be sealed with a rubbersheet to prevent the biogas from leaving the cell. In the cell air and water can be added to insure a fast (1-2 years) and complete degradation of the organic waste.

\section{ANAEROBIC FERMENTATION IN CLOSED DIGESTERS-NSR, HELSINGBORG}

A closed digester for anaerobic fermentation of organic wastes was built in Helsingborg at the landfill Filborna in 1995/96.

The waste which is delivered to the plant is pumped into a receptiontank of concrete. From this the waste is then transported to a heatexchanger where the waste get a temperature of $70^{\circ} \mathrm{C}$ to garanty a good hygienic result. Before the waste is pumped into the two digesters the temperature is lowered to round $37^{\circ} \mathrm{C}$. The digesters has a volyme of each $3000 \mathrm{~m}^{3}$.

In total the capacity in the plant is around $30000-40000 \mathrm{~m}^{3}$ fluid waste per year. This will give a amount of biogas corresponding to an effect around $5 \mathrm{MW}$. 